\title{
WAR AND RECONSTRUCTION*
}

\author{
By Dr. Julian S. Huxley, F.R.S.
}

$\mathrm{E}^{\mathrm{v}}$ ERYONE realizes, though with very different degrees of awareness and to the accompaniment of feelings that range from ardent hope to sullen resistance, that this War is bound to be followed by radical changes in the structure of separate societies and the organization of the world. In this connexion, biological analogy is helpful not only in creating a general background against which to envisage the coming change, but sometimes in suggesting detailed points in the new order.

In the first place, biology reminds us that change is the normal (though not the universal) rule of life, that certain aspects of biological change can legitimately be called progress, and that man is biologically speaking a very recent type, whose social organization is still primitive in the extreme when looked at in the light of evolution. The lesson of biology for the resistant conservative is therefore that his resistance to change in general is not only useless but also immoral.

But biology has also a warning for the overenthusiastic progressive. Biological change has normally (though probably not universally) been a very gradual process. The rate varies considerably as between different lines of descent, and at different periods of the world's history, but the change is normally effected through step-by-step alterations of existing organization. In general, it is as frequent for old organs to be converted to new uses as for wholly new organs to be evolved. The zeal of the revolutionary for getting rid of the old system root and branch is thus likely to be wastefully destructive and in the long run to delay progress.

From the point of view of human biology, what are the chief features of the present time which have altered man's social environment so much that corresponding alterations of social organization are needed to meet them-and which, incidentally, have helped to bring about the War?

The first is the increase in the efficiency and speed of transport and communications, accompanied by the virtual abolishing of frontier space for expansion. This is forcing the remotest regions of the world into often unwilling interaction. It on the one hand provides a potential basis on which world unity could be built, and on the other makes the lack of that unity more and more disadvantageous. * Substance of the British and American Association Lecture
delivered before the American Association for the Advancement of delivered before the American Association for
Science at Columbus, Ohio, on December 30 .
The second is the increase in the potential of power available to States. This is most dramatically seen in respect of war. Armaments have become many times more efficient during the last twenty years. The result is that war has grown out of scale with its function. During many centuries it operated, wastefully enough, yet with a certain efficiency, in adjusting the variations in the balance of power caused by geographical discovery, economic change, and population pressure. But to-day, both its destructiveness and its expensiveness have got out of hand, and have become wholly incommensurate with any positive results which its agency may help to accrue. This, however, is not the only way in which State power has shot up. The dictator regimes have taken into their own hands the organization of economic power and also of the power of opinion. They are in literal truth totalitarian.

The biological analogy shows that for competing nation-States merely to respond to this challenge by corresponding permanent changes in their own organization (however necessary such changes may be as a temporary measure) would be to court disaster. Size and armament alone lead up a culde-sac. The giant reptiles of the Mesozoic included the largest carnivores the world has ever seen, like the Tyrannosaurs, and the most heavily armoured animals, like the Stegosaurs and the Ceratopsians. They answered bulk with bulk, aggressive with defensive warfare. But they were all doomed to extinction as soon as the changing environment gave the insignificant but brainier little mammals their chance. The contraction of the world due to better communications provides the corresponding change of environment to-day ; brain-power spent on devising new systems is inevitably destined to supplant the present armoured monsters of the nation-State era. The only question is whether it shall be now, or after more waste and destruction.

A third fact of the utmost importance in the modern world is the search for a new mystic, a new super-personal driving force. Traditional religion of the supernatural type has lost both ground and grip : the curious materialist-idealist compound which expressed itself in the nineteenth century's belief in the inevitability of progress, in the power of knowledge to mould human nature and produce almost millennial prosperity and peace, has wilted in disillusion. In their place, three great nations have already erected new 
pseudo-religions, all of them involving the glorification of the State. The most radical is that of Nazi Germany, which uses the race-concept as its mystical basis, while for Italy the mystic is the nation, and for Russia the millennial picture of the truly Communist society, when Government will wither away.

In all these cases, however, the mystical driving concept is linked with the national organization of power: and this inevitability has brought a recrudescence of intolerance, persecution, and cruelty which has contributed largely to the final shattering of the belief in progress in other nations. History teaches us, however, that intolerant persecution always arises when an unintelligent mystic doctrine is held with such intensity that the end is deemed to justify the means; and that the persecution will be violent and brutal when the mystic doctrine is bound up with the system of power.

Two by-products of this situation are to be noted. First, the unprecedented refugee problem which it has created - unprecedented partly because of the violence and extent of the persecution, partly because of the nationalist unwillingness of other States to absorb new alien elements; secondly, the distortion of truth which it has brought about, with resultant lowering of the quality of scientific research in the countries concerned. A biological analogy here would seem to be the incredibly small size of the brains of the giant Mesozoic reptiles.

The fourth great feature of the present is the trend away from laissez-faire and individualism towards planned organization and collective action. During the period of rapid industrial expansion in the nineteenth century, laissez-faire individualism. worked well enough, in spite of all its attendant horrors of slums, exploited labour and imperialist expansion. Indeed, it is probable that no other system could have so rapidly mastered the forces and resources of the world. But to-day, like war, it is defeating its own ends and proving unsuitable for its functions. It is proving unsuitable for four reasons ; first, because unplanned individualisms, as the world contracts, tend to cancel each other out; secondly, because its basic time-span is too short for many types of projects - the individual demands a return on his money within his own lifetime, or at least for his children. Thirdly, because the agent is too localized; the individual demands a return to himself or to his family, whereas many projects are desirable by making a return to the community in general, through better health, greater taxable capacity, higher standard of living and increased consumption demands, and so on. Fourthly, because it prompts the recurrent vicious cycle of trade boom and trade depression.
Already the world has moved far from simple laissez-faire; but the present system is a compromise, and the agencies of collectivized planning are as yet extremely imperfect.

The fifth point is the gradual evening out of world resources in raw material and power. This has been accomplished partly by new methods (for example, utilizable nitrogen from the air instead of from Chilean nitrate beds); partly by artificial substitutes (synthetic dyestuffs; artificial silk; plastics); partly by new transformations of old sources of material or power (motor spirit from coal; hydro-electric power); partly by substituting new raw materials for old (aluminium for heavy metals). The net result has been that, while many inequalities of distribution remain (U.S. helium ; Canadian nickel, etc.), the bulk of natural resources is becoming much more uniformly spread over the habitable globe.

The sixth striking feature of our time is the great increase in leisure-some of it in the compulsory form of unemployment and retirement at comparatively low ages. (During actual war, much of this leisure is of course abolished.) The totalitarian countries have made some interesting attempts to provide social organizations for the better utilization and enjoyment of leisure, but so far in other countries the individualistic laissezfaire tradition, which tends to regard Statecontrolled organization as undesirable interference, has prevented any real evolution in this direction.

Seventhly, there is a new approach to colonial problems. Partly this is due to the jealousy of the 'have-nots', a normal phenomenon whipped up to exceptional intensity under the pressure of nationalistic feeling; but in large measure it is due to a new attitude, which has already found expression in the mandatory principle, and to a dawning realization of world unity and the part to be played therein by peoples whose social development has been retarded.

We have drawn one evolutionary analogy - that of the over-armed and under-brained reptiles of the late secondary era. We cannot, however, suppose that the subsequent course of biological evolution will serve as a pattern for the next phase in our own history. This would imply that the overarmed nation-States would disappear and their places be taken by smaller nations more concerned with flexibility and intelligence of social behaviour. This is ruled out by the shrinkage of the world. Do not let us forget that man differs from all other major biological types in consisting of but a single inter-fertile species, in possessing much greater control over the environment, and with the power of forming much larger communities. The only possible climax for such a type is that it should extend over the entire habitable globe in the form 
of a single community, whatever the organization of that world community may be. All intermediate stages, of racial, tribal, national groups, are, in the long perspective of evolution, inevitably unstable.

But for the immediate future, both biological analogy and historical experience demand a stepby-step advance. Some functions are sufficiently advanced to be put on a world footing without dislocation, while for others the step can only be on to a regional basis. The chief functions which could be stepped up to a world platform are those concerned with primary products and raw materials, with certain aspects of research and of communications, and with sea-power. The chief functions for which we must be content with the intermediate regional set-up are the political, in the broad sense of the word.

Let me amplify this second point first. National culture and tradition, usually combined with language, is the strongest political force in the world to-day. So-called race problems, when analysed, always turn out on analysis to owe their acuteness to differences in culture and economic level which happen to be associated with genetic differences. It is wholly premature to envisage any immediate world-government which could stand up to the tensions introduced by existing differences in national culture. Region. ally, however, there is a hope.

The U.S.S.R. has already established a federal system over one-sixth of the world's land area. Pan-America is beginning to emerge. The present struggle between Japan and China could without too great difficulty be forgotten in a Far Eastern federation. Malaya and tropical Africa are destined by Nature to take their place as world regions as their inhabitants progress toward economic efficiency and political self-government. Finally there remains Europe, in the cultural sense of the area where Western civilization arose and where it still flourishes, however impeded by the barriers of nationalism and the counter-currents of totalitarian philosophy - regionally the geographic Europe minus European Russia but plus the Asiatic and African fringes of the Mediterranean Sea.

The most urgent political post-War task is the settlement of Europe. It is here that the greatest number of powerful nationalisms occur, here that they are most crowded, here that the ownership of tropical territories is chiefly concentrated. Geography and history dictate a regional solution for this area, now torn by war. And the War is a civil war, between different representatives of the European tradition-the tradition based on Greece, on the Roman Empire, on Christianity, on representative government, on the spirit of modern science and industry.
Yet the differences between the various nations or groups of nations within Europe are so great, their separate traditions within the enfeebled European tradition so strong, that it would be hopeless to attempt at one bound a full-fledged federal system like that of the United States. On the other hand, a League system, even if confined to Europe, will not be enough; the experiences of the League of the American States prior to their federation reinforces the lesson of the last twenty years. A League system will not work because it is a contradiction in terms : the abso. lute sovereignty of its member States is irreconcilable with collective action for the benefit of the whole. Some abrogation of sovereignty -in other words some step towards federation-is essential.

What is the minimum degree of federation which would be effective? An executive organ, an advisory organ, an organ of discussion, a training organ, an organ of opinion, a budget, and, in the present state of the world, alas, an armed force. The executive organ would be restricted to a council, in which smaller countries could be represented groupwise. The organ of discussion would be some sort of assembly, not necessarily elected by Western democratic methods, but representing functions as well as regions. For training there is needed some form of international staff college; for moulding opinion back toward unity and away from nationalist separation, a broadcasting service and perhaps a film unit and newspapers and periodicals. The budget might be raised as a percentage levy or in various other ways: the one essential is that it should be adequate in amount -at least a hundred million pounds per annum. Inadequacy of finances was one of the reasons for the failure of the League. The extent of the inadequacy may be seen from the fact that the total of the contributions of member States during any of the last few years was just about as much as what the London County Council spent annually on main drainage alone! As for armaments, if the European council alone disposed of military planes, heavy tanks and heavy artillery (the manufacture of which cannot be kept secret), effective disarmament, both qualitative and quantitative, could be imposed on member nations, and yet Europe as a whole would dispose of a powerful force. The units of the force should presumably be stationed whenever possible in the territory of small nations; that would be an important contribution on their part to collective security.

The budget would be mainly employed, apart from armaments, on long-term development schemes which would not readily attract private capital-partly in Europe (and there mainly in the less-developed nations, though special projects 
could be contemplated in any country), partly in the colonial dependencies. But a reasonable fraction would be reserved for the other European agencies and for leisure organizations on a European scale.

To these last I shall return. Meanwhile let us consider world organization. The most important of these would deal with primary products and raw materials, and their basic function would be first to iron out the vicious cycle of slumps and booms, and secondly to promote a higher standard of living through higher consumption. The League has been blamed, perhaps rightly, for its lack of proper organization on the economic side. It is, however, fair to remember that in 1919 the machinery for large-scale control of raw materials was virtually non-existent. Most of it was called into being by the great depression of 1929 and subsequent years. It exists in the form of cartels and other international schemes for commodity control. From the technical aspect of economic machinery, these have been much improved during the last decade : it remains to alter their direction, to harness them in the interests of consumption and of the general public instead of permitting the dominance of a policy of restriction and shortterm profits for sectional interests. From the technical point of view, the provision of really adequate buffer pools and the wholehearted application of scientific research would also lead to improvement.

They would be under a Permanent Commodities Commission of the League of Nations or whatever world international organization took its place. In addition, such a body would have the duty of canalizing world long-term investments for development purposes, partly in the form of rural loans and the like, partly indirectly through the setting up of development commissions and of what might be called international chartered companies, to promote the general development of backward areas. Development commissions, somewhat on the pattern of the Tennessee Valley Authority, would be suitable for self-governing areas where co-operation can be effected with local government authorities; while the chartered company type of-organization will be needed for dependent (non-self-governing) territories. Such bodies would (as with similar semi-public organ. izations like the London Passenger Transport Board) be compelled to return all profits above a fixed rate into the area for which they were responsible.

We may take colonies next. Here, as with Europe, the task is to steer a safe course between the Scylla of doing nothing and the Charybdis of attempting too much and seeing the shaky edifice collapse. It is easy enough to say, as many people are saying, that all colonies should be handed over in the immediate future to an international commission. But would it work? Those who know something about native peoples and the problems of tropical administration say no. There must be somewhere in the system a firm organ of authority and an adequate focus for the loyalty both of those administered and those whe administer them. Until the incipient federation of Europe that we have outlined grows into a true federal government, and until training and tradition have produced an esprit de corps in the international administrative service, these essential organs of colonial administration will not exist internationally. To take a somewhat remote and yet valid biological analogy, before the adequate development of the cerebral cortex, lower vertebrates had to delegate most of their behaviour to a rather poorly co-ordinated system of reflexes and simple instincts.

The remedy would seem to be retention of the principle of national and executive authority at the periphery, with a reasonable and increasing degree of international non-executive control at the centre. The separate colonies and their administration would remain British, French, Belgian, and so on, though they should all be put on the footing of mandates, and the Mandates Commission strengthened by the grant of powers of investigation on the spot in addition to mere review of policy. Under the European council would be established a colonial commission, truly international, with small but picked international staff of research workers, experts and travelling advisers, and the power of allocating considerable grants out of the European common budget for education, for health, for conservation, for roads and other public works.

It would be desirable that a small but progressively increasing fraction of the technical and perhaps later of the administrative posts in the local service should be thrown open to nationals of other countries; but the appointments should be in local hands, not in those of the international authority.

A somewhat similar system works quite successfully between the Federal and State authorities in the Tennessee Valley Authority, and it ought to work well enough in the colonial sphere. The scheme would have to be modified in the minor colonial areas, such as the Caribbean and the Pacific, to allow of the participation of other powers, for example, the United States and some of the British dominions.

Do not let us forget that international administration is per se no solution of the basic colonial problem, which is the development of the colonial territories and their inhabitants towards self- 
government. It could only help at the European end, in reducing jealousy among the great powers. But even the partially international scheme set forth above would remove most of the political objections to the transferring of colonial mandates to other powers.

Meanwhile the world organization, too, through its international chartered companies, its world loans, and its expenditure on research, would be aiding in the progress of the tropical countries. The international staff college would have its colonial section, and after perhaps a generation, there would have been built up a truly international esprit de corps among the staff.

I mentioned the growth of leisure and the need for its better organization. This is especially urgent in Europe, for it will be largely through such organization that the people of its separate countries will be able to understand the European tradition and to participate in it, only so to experience the greater European loyalty which will render the lesser national loyalties innocuous, a source of local but co-operative pride instead of a source of jealousy and hate.

To do this, the democracies must learn from the totalitarian States; they must build up their own leisure organizations, and then extend the principle internationally. One can think of so many ways in which such organizations could promote "life, liberty and the pursuit of happiness" on the international plane. Properly organized travel in international parties; youth hostels, walkers' and climbers' hostels, all over Europe. International festivals like Salzburg in the old days, or Oberammergau, but more numerous and made available to many more people; an international system of holiday camps, of summer schools, of study and hobby groups, of retreats, dotting Europe from end to end. The whole could easily be linked up with the extension of the exchange system which will be necessary on the educational side-exchange of undergraduates, of graduates, of teachers and professors, to a certain degree of schoolboys ; and also with international schemes of refresher courses for administrators and professional men of every description, and of adult education. One may even envisage the substitution of citizen service for military conscription, and the placing of that, too, on a broad inter-European basis. In all such ways, Europe could become a reality to its inhabitants, and the onward flow of its great cultural tradition would be reinforced.

Let us try to envisage what improvements such changes would bring about. Nationalism and self-determination would not disappear; but they could be relegated to the cultural sphere, as has been done within the U.S.S.R., and banished from that of economics and power politics. Political boundaries and national Governments would con. tinue to exist ; but their importance, and especially their importance in causing trouble, would be reduced. The risk of conflict between major regions would remain until the time was ripe for world as opposed to regional federation. But the financing of development schemes in the poorer or less advanced countries, and the reduction of economic distress by ironing the bottom out of depressions and by planned schemes for world production and distribution of raw materials and primary products, would remove some of the chief causes of unrest and war.

Friction and difficulty will remain: we have the fundamental biological analogy of hostile symbiosis of the parts within the body to remind us of that. But man and his societies are organisms, albeit with their own unique nature; and the equally fundamental biological analogy between animal and social evolution shows us that the difficulties can be overcome, and the friction of the parts subordinated to and even utilized for the benefit of the whole.

But do not let us delude ourselves into thinking that it will be easy. Wishful thinking issuing in impractical schemes is one of man's unique biological attributes. Historical experience demon. strates that the most important line of evolutionary progress has been through the improvement of brain mechanism, notably the mechanism for acquiring knowledge and correlating it with action.

The corresponding social machinery is yet in its infancy. The end of the War will face the world with a task for which it is ill prepared. But again, do not let us attempt any ideal or complete plan, any grandiose scheme for which the world is not ripe. That was one of the causes of the League's failure : it was an attempt to impose a ready-made plan, and public opinion was insufficiently prepared for any idea of world citizenship. Rousseau and the Encyclopædists had been preparing opinion for a radical change in society for half a century; without that, the French Revolution would have been a fiasco. The idea of supernational organization had not penetrated beyond a limited circle of intellectuals, and even they had not had time to work out their ideas in detail, before Wilson sought to impose it in reality. To-day we have at least had twenty years of discussion, together with some bitter if salutary experiences. If the leaders of thought in the various nations can now work out a less pretentious but more workable plan, and at the same time can prepare public opinion for the idea of a dual citizenship, national and world, this War may be the occasion for taking a small but decisive step away from war and towards a world organization of humanity. 